" That the additional accommodation required should therefore be sought for in the establishment of a separate institution, either as supplementary to the present asylum; or as a distinct second County Lunatic asylum; and it appears desirable that such should not be con. structed for less than 200 patients, with the means of increase.

" "That upon the question of the economical and other advantages to be looked for in the establishment of an auxiliary institution adapted for the reception of chronic and harmless patients only, the visitors thought it advisable to ascertain (by inquiries sent round) the opinion of the Superintendents of the different County asylums in England before making any recommendation upon the subject. From the information thus obtained, it appears to be the general feeling of those authorities that no scale of diet or mode of living lower than that which prevails in the ordinary County Asylums could be properly applied in the chronic and harmless cases referred to ; and since every diet table must be sanctioned by the Lunacy Commissioners before adoption, it is not probable that any saving could be calculated upon under this head. It is in the economy of construction and management of an institution for the chronic and harmless only that saving is to be anticipated, but the prevailing opinion is that much might be saved under these heads. On such grounds the visitors would have been disposed to recommend the establishment of an institution of this description as supplemental to the present County Asylum, which, when relieved from the accumulation of chronic cases, ought to be sufficient to meet the requirements of all first admissions for many years to come. They believe, however, that before any decision is arrived at as to the precise charaoter of the new institution, some further inquiries should be made. They consider that the situation to be selected should, under any circumstances, be such as to afford easy communication with the County Asylum, either by road or railway.

" As long as the inmates of the asylum went on increasing as they had been of late, they would, if necessary, have to provide on the average for thirty additional lunatics every year. The number in the asylum in the year 1857 was 407 , and in 1863595 . The Visiting Justices were not entirely satisfied that chronic lunatics required as much food as was required in recent and curable cases. But all the Superintendents of County Asylums, though differing in many other points, were opposed to this view, and in all probability the Commissioners would not, therefore, sanction any lowering of the diet. The proper course now to be taken was for the Deputy Clerk of the Peace to publish a notice that at the next Quarter Sessions a proposition would be made for the appointment of a Committee of Justices to consider the whole subject of additional accommodation for pauper lunatics:" -The Lancet, April 9.

\title{
Prosecution for keeping an Unlicensed Lunatic Asylum.
}

Mrs. Sophia Leander, of Zion House, Turnham Green, appeared on her recognizance to answer a charge of misdemeanour for having received into her house two or more lunatics, the said house not being a licensed asylum or duly registered to receive lunatics under the provisions of the 8th and 9th Victoria, cap. 100, sec. 44.

Mr. Montague Smith, Q.C., and Mr. Giffard were counsel for the prosecution; Mr. Serjeant Ballantine and Mr. Robinson for the defence.

The prosecution was at the instance of the Commissioners of Lunacy, 
who were appointed by Act of Parliament to superintend lunatic asylums and houses where lunatics are kept. About 1855 the defendant opened Zion House for the reception of women of diseased intellect. The institution was supported partly by voluntary contributions and partly by those of the friends of the inmates. At first it was conducted by a committee of ladies, but ultimately the whole management devolved upon Mrs. Leander, the defendant. The attention of the Commissioners was called to the establishment as early as 1857 , and various visits were made to it by two of their body. They were at length of opinion that from the paucity of its resources the house could not be conducted as it ought to be. The law enacted that no person should be allowed to have more than one lunatic in his house, and if any one received two or more lunatics, unless the house was an asylum and registered, or unless it was duly licensed, he should be doemed guilty of a misdemeanour. Many persons having been received into Zion House, and the defendant not being able to comply with the requirements of the Act, the Commissioners felt it their duty to institute the present proceedings. They had no wish to injure the defendant, but it was necessary to put houses of this kind under the supervision which the Legislature required for the safety and protection of the unfortunate persons who were received into them.

Dr. Thomas Beach Christie, of Pembroke House, Hackney, stated that on April 19, he went to Zion House with Mr. Lutwidge, one of the Lunacy Commissioners, and saw Mrs. Leander. He found about eighty persons in the house, and examined several of them. Among others were Julia Robinson, Sarah Medwin, Susan Gladman, Elizabeth Stuart, and Maria Burgess, the whole of whom he found decidedly of unsound mind. On cross-examination by Mr. Serjeant Ballantine he said Mrs. Robinson was subject to delusions, which he considered to be unsoundness of mind. The distinction was difficult to be drawn between weakness of intellect and unsoundness of mind, but he was not aware of any case where a person not able to take care of himself had been refused admission to a lunatic asylum. Susan Gladman's case was that of a total loss of memory. She could not tell whether she had been in the asylum for years, months, or days. Burgess was a confirmed idiot, and totally incapable of understanding anything. Stuart was labouring under chronic mania, with excitement. On re-examination, the witness said that Robinson's physiognomy indicated that she was insane, and he had not the slightest doubt that she was of unsound mind. With regard to Gladman, loss of memory arose from a diseased mind. He saw other inmates whom he did not know, and their state was that of idiots.

By the Judge: There was no definite line between a low state of intel. lect and idiocy, - where the one ended and the other began.

Mr. Thomas Martin, chief clerk in the office of the Commissioners in Lunacy, proved that Zion House had neither been registered nor licensed.

This was the case for the prosecution.

Mr. Serjeant Ballantine then addressed the jury on behalf of the defendant. The case, although one of great importance, nevertheless lay in a very narrow compass. He could not complain of the mode in which the prosecution had been conducted towards the defendant, who, whether she had violated the law or not, beyond all question had been actuated by no selfish or improper motive. She had been the active instrument of what he believed to have been intended to be a very valu. able charity, and had endeavoured with all her characteristic energy to 
serve the unfortunate inmates of her establishment. The question, however, was, had she or had she not violated the law ? Becanse, if she had, whatever her motives or her object might have been, she was amenable to justice. He agreed that it was the duty of the Commis. sioners in Lunacy to take care that no asylum should be improperly conducted, and to protect those who were unable to protect themselves; but there was a class of people very different from those regarded as lunatics or idiots, who required equal care. There was a vast number of persons whose intellects were dull, whose powers of appreciation were small, and whose memory was very considerably weakened-especially those who had suffered from the terrible calamity of epilepsy-who, without being insane or lunatic, were almost or entirely incapable of taking care of themselves. For these an asylum was wanted different from that which was suited to persons of unsound mind. The wealthy had no difficulty in finding asylums of that kind for relations who were unfortunately afflicted. There were advertisements in the 'Times' daily of such asylums from one end of the country to the other; but nothing of the kind existed for the poor; for them there was no refuge but the workhouse, and it was for the poor that the institution in question had been established and carried on for many years. The evidence, he submitted, was most unsatisfactory. For the purpose of placing a person in a lunatic asylum the certificate of two medical men was imperatively required, and the world knew what fancies and theories medical men had upon the subject of insanity : but here was a case in which the Commissioners rested the whole prosecution upon the testimony of a single man. The learned serjeant urged upon the jury that the defendant had acted upon the honest belief that she was quite justified in the course she was pursuing, and that under all the circum. stances she was entitled to a verdict of acquittal.

Mr. Baron Bramuell, in summing up the evidence, observed that the defendant was indicted, not for doing anything which was wrong in itself, or which, for aught the jury knew, might not be praiseworthy in its way, but for disobedience to an existing law. They must be satisfied that the cases which had been mentioned by Dr. Christie were cases of insanity which brought the defendant under the operation of the law. For his part, although medical men were often heard in courts of justice to define insanity and lunacy, he thought ordinary men of the world were just as well qualified to form an opinion on those matters as they.

The jury, after a short consultation, returned a verdict of " Guilty."

Mr. M. Smith, Q.C., said, as the object of the prosecution was to close the asylum, he would not call on the Court for any sentence if that point could be attained.

Mr. Baron Bramioll said the best way would be to hold the defendant in her own recognizances to appear at a future day if necessary, and then arrangements might be made in the meantime for the removal of the present inmates of Zion House.

The suggestion of the learned Judge was adopted, and the defendant left the Court.-Central Criminal Court, June 8.

\section{The Flushing Lunacy Case.}

"IT is satisfactory to perceive that the Court of Criminal appeal has refused to confirm the objections raised by Mr. H. T. Cole, the counsel for the defence in the case of Samuel Porter, found guilty at 